\title{
Droplet infiltration dynamics and soil wettability related to soil organic matter of soil aggregate coatings and interiors
}

\author{
Miroslav Fér ${ }^{1 *}$, Martin Leue ${ }^{2}$, Radka Kodešová ${ }^{1}$, Horst H. Gerke ${ }^{2}$, Ruth H. Ellerbrock ${ }^{2}$ \\ ${ }^{1}$ Czech University of Life Sciences Prague, Faculty of Agrobiology, Food and Natural Resources, Dept. of Soil Science and Soil \\ Protection, Kamýcká 129, CZ-16521 Prague 6, Czech Republic. \\ ${ }^{2}$ Leibniz-Centre for Agricultural Landscape Research (ZALF), Institute of Soil Landscape Research, Eberswalder Straße 84, Müncheberg, \\ 15374, Germany. \\ * Corresponding author. Tel.: +420 2243827 57. E-mail: mfer@af.czu.cz
}

\begin{abstract}
The organo-mineral coatings of soil aggregates, cracks, and biopores control sorption and macropore-matrix exchange during preferential flow, in particular in the clay-illuvial Bt-horizon of Luvisols. The soil organic matter (SOM) composition has been hypothesized to explain temporal changes in the hydraulic properties of aggregate surfaces. The objective of this research was to find relations between the temporal change in wettability, in terms of droplet infiltration dynamics, and the SOM composition of coated and uncoated aggregate surfaces. We used 20 to $40 \mathrm{~mm}$ sized soil aggregates from the Bt2 horizon of a Haplic Luvisol from loess that were (i) coated, (ii) not coated (both intact), and (iii) aggregates from which coatings were removed (cut). The SOM composition of the aggregate surfaces was characterized by infrared spectroscopy in the diffuse reflection mode (DRIFT). A potential wettability index (PWI) was calculated from the ratio of hydrophobic and hydrophilic functional groups in SOM. The water drop penetration times (WDPT) and contact angles (CA) during droplet infiltration experiments were determined on dry and moist aggregate samples of the three types. The decrease in the CA with time was described using the power function $\left(\mathrm{CA}(t)=a t^{-b}\right)$. For dry aggregates, the WDPT values were larger for coated as compared to uncoated regions on the aggregate surfaces, and increased with increasing PWI value $\left(R^{2}=0.75\right)$. The $a$ parameter was significantly related to the WDPT $\left(R^{2}=0.84\right)$ and to the PWI $\left(R^{2}=0.64\right)$. The relations between the $b$ parameter and the WDPT $\left(R^{2}=0.61\right)$ and the PWI $\left(R^{2}=0.53\right)$ were also significant. The WDPT values of wet soil aggregates were higher than those of dry aggregates due to high water contents, which limited the droplet infiltration potential. At the wet aggregate surfaces, the WDPT values increased with the PWI of the SOM $\left(R^{2}=0.64\right)$. In contrast to dry samples, no significant relationships were found between parameters $a$ or $b$ of $\mathrm{CA}(t)$ and WDPT or PWI for wet aggregate surfaces. The results suggest that the effect of the SOM composition of coatings on surface wettability decreases with increasing soil moisture. In addition to the dominant impact of SOM, the wettability of aggregate surfaces could be affected by different mineralogical compositions of clay in coatings and interiors of aggregates. Particularly, wettability of coatings could be decreased by illite which was the dominant clay type in coatings. However, the influence of different clay mineral fractions on surface wettability was not due to small number of measurements ( 2 and 1 samples from coatings and interiors, respectively) quantified.
\end{abstract}

Keywords: Aggregates; Clay and organic matter coatings; WDPT; Contact angle; DRIFT spectroscopy.

\section{INTRODUCTION}

Aggregate coatings and biopore walls are characteristic soil structural features (e.g., Gerke and Köhne, 2002; Kodešová, 2009; Kodešová et al., 2011, 2015; Rogasik et al., 2014) that are of great importance when attempting to describe preferential flow and transport processes in soils (e.g., Gerke, 2012; Kodešová, 2009; Kodešová et al., 2008, 2009, 2010, 2012). Clay-organic coatings often cover aggregates and biopores in the clay-illuviation Bt-horizons of Luvisols (IUSS Working Group WRB, 2014). These coatings considerably restrict interactions between pores inside and outside of the aggregates (e.g., Fér and Kodešová, 2012; Gerke and Köhne, 2002; Kodešová et al., 2012). Earthworm burrow walls can also be coated by the earthworm casts, which often have different soil chemical and physical properties than the bulk soil (Jouquet et al., 2008; Lipiec et al., 2015; Schrader et al., 2007). The mass exchange (e.g. water flow and solute transport) between macropores (i.e., earthworm burrows and cracks) and the matrix domain (i.e. pores outside and inside of aggregates or biopore walls) is decreased mainly due to the lower permeability of fine-textured coatings, in comparison to that of aggregate interiors (Fér and Kodešová, 2012; Gerke and Köhne, 2002; Köhne et al., 2002).
In addition, smaller sized pores can restrict larger molecules (e.g., Brilliant Blue FCF) from passing through the coatings (Kodešová et al., 2012; Nobles et al., 2003, 2004). Under dry conditions, organo-mineral coatings may decrease the wettability of aggregate surfaces due to an increased hydrophobicity of the soil organic matter (Goebel et al., 2005; Vogelmann et al., 2013).

Measurements of water drop penetration time (WDPT) and water drop contact angles (CA) have often been used to study wettability of soils. Several factors could affect soil wettability, one of them is clay content. For disturbed soil samples, clay content increased WDPT and CA in non-repellent soils (Leelamanie and Karube, 2011; Leelamanie et al., 2010), whereas in slightly to severely repellent soils, decrease these values (McKissock et al., 2002; Zavala et al., 2014). However, soil wettability is mainly controlled by the content of soil organic matter (SOM) (e.g. Kořenková et al., 2015). It was shown (e.g., Blanco-Canqui and Lal, 2009; Goebel et al., 2008; Lachacz et al., 2009; Vogelmann et al., 2013) that soil water sorptivity decreased exponentially with increasing SOM content. Czachor et al. (2013), Leelamanie and Karube (2007), Vogelmann et al. (2013), and Woche et al., (2005) also reported a non-linear increase of the contact angle with SOM content. 
Relations between SOM and wettability could be clearer when considering not only the content, but also the composition of the SOM (e.g., Capriel et al., 1995; Ellerbrock et al., 2005). The SOM composition can be determined in terms of organic matter functional groups using Fourier transform infrared (FTIR) spectroscopy (e.g., Demyan et al., 2012) or nuclear magnetic resonance (NMR) spectroscopy (e.g., Celi et al., 1997; Schaumann et al., 2013). The potential wettability of SOM was characterized by the ratio between the FTIR signal intensities of hydrophobic aliphatic $\mathrm{C}-\mathrm{H}$ groups and hydrophilic $\mathrm{C}=\mathrm{O}$ groups (Ellerbrock et al., 2005). This ratio was proposed as a potential wettability index (PWI) of SOM (Leue et al., 2013). A higher value of PWI means that the SOM has relatively more $\mathrm{C}-\mathrm{H}$ in comparison to $\mathrm{C}=\mathrm{O}$ functional groups, and indicates decreased wettability of the surfaces. Infrared spectroscopy in the diffuse reflectance mode (DRIFT) can be used to obtain infrared spectra from intact sample surfaces. DRIFT spectra were used to determine the ratio between hydrophobic and hydrophilic functional groups in the SOM (PWI) of intact aggregate coatings by Ellerbrock et al. (2009) and Leue et al. (2013). For the clay-organic coatings on aggregates from a Bt horizon of a loess-derived Luvisol, a nonlinear relationship between the PWI and soil wettability (expressed as WDPT) was recently found by Leue et al. (2015).

Contact angles have often been expressed as a single value characterizing initial drop contact with the surface, and are not often determined as a function of time (Bachmann et al., 2013). When analyzing the process of water drop infiltration into aggregate surfaces, the contact angles between aggregate surface and water are, however, dynamically changing. Leelamanie and Karube (2009) measured the exponential decrease of CA with time using artificially hydrophobized sand. Chau et al. (2014) studied the temporal change of the contact angle on different disturbed soil samples taken from a boreal forest whereby they observed an exponential decrease in contact angle during the initial 5 minutes interval with no apparent trend thereafter. Furthermore, Bachmann et al. (2013) also observed a decreasing trend of CA with time on homogenized sandy soils. However, the CA dynamics were not quantified nor described using analytical equations in any of these studies. To the best of our knowledge, previous studies were performed on disturbed soil samples. The dynamic measurements of CA of droplets infiltrating into intact soil aggregate surfaces have not yet been reported.

In this study, we hypothesize that for a clay-illuvial horizon of a Luvisol, the SOM composition of aggregate coatings differs from that of the aggregate interior, which results in different droplet infiltration and CA behavior at the intact coated and uncoated aggregate surfaces. We further hypothesize that an exponential equation may be applicable to express the changes in CA with time. We assume that (i) the actual soil wettability assessed as WDPT is related to the potential wettability of the SOM at the intact soil aggregate surfaces in terms of the PWI and (ii) the PWI should be related to parameters of the equations that describe the decrease in the water droplet CA with time. To prove these hypotheses, we studied the characteristics of aggregate surfaces with and without clay-organic coatings obtained from the Bt horizon of a Haplic Luvisol developed on loess. The droplet infiltration into the surface of dry and moist soil aggregates was evaluated by WDPT and CA measurements. An exponential and a power equation were applied to express the CA decrease in time. Finally, the PWI value obtained from DRIFT spectra of sample surfaces was related to the actual wettability (assessed as WDPT), and to the parameters of a power function characterizing CA dynamics. An additional task of this study was to evaluate the clay mineralogical composition of coatings and interiors of aggregates (using Xray diffraction) as another potential factor affecting soil surface wettability.

\section{MATERIAL AND METHODS}

Site, soil and sample preparation

Soil samples were collected from the experimental station of the Crop Research Institute in Hněvčeves (a village located near the city of Hradec Králové, the Czech Republic). The elevation of the experimental fields is $272 \mathrm{~m}$ above sea level. The annual mean temperature was $8.5^{\circ} \mathrm{C}$ over the last 30 years and the mean annual precipitation was $618 \mathrm{~mm}$. Soil sampling was performed immediately after the harvest of wheat in July 2009. Soil type was classified according to the World Reference Base (IUSS, 2014) as Haplic Luvisol with loess as the parent material. Five diagnostic horizons were identified in the soil profile: A1, 0 to $25 \mathrm{~cm}$; A2, 25 to $35 \mathrm{~cm}$; Bt1, 35 to $75 \mathrm{~cm}$; Bt2, 75 to $102 \mathrm{~cm}$; and $\mathrm{Ck}, 102$ to $130 \mathrm{~cm}$. The basic soil properties of studied Haplic Luvisol, evaluated by Kodešová et al. (2012), are shown in Table 1. Kodešová (2009); Kodešová et al. (2008, 2009) reported intensively developed blocky, and large and long prismatic aggregates in the Bt1 and Bt2 horizons, respectively. Soil aggregates in the $\mathrm{Bt} 1$ and $\mathrm{Bt} 2$ horizons were covered by clay and organic matter coatings. The coatings development in these horizons has been affected by the agricultural management (Jirků et al., 2013; Kodešová et al., 2011) causing frequent aggregate destruction in the top soil and accelerated clay migration within the soil profile. Studies by Kodešová et al. (2009) and Kočárek et al. (2010) showed that water flow and contaminant (in this case herbicide) transport was accelerated in both Bt horizons, due to preferential flow caused by soil aggregation and the restrictive impact of clay and organic matter coatings covering soil aggregates on water and solute transfer between macropores and soil matrix. Enhanced preferential flow in the $\mathrm{Bt} 1$ and $\mathrm{Bt} 2$ horizons and the low permeability of aggregate coatings (with respect to a Brilliant Blue FCF dye) was shown on the images of stained fieldscale sections and micromorphological images of stained thin soil sections, respectively (Kodešová et al., 2012). Leue et al.

Table 1. Depths of soil horizons and basic soil properties determined on disturbed soil samples: oxidizable organic carbon content $\left(\mathrm{C}_{\mathrm{ox}}\right)$, clay $(<0.002 \mathrm{~mm})$, silt $(0.002-0.05 \mathrm{~mm})$ and sand $(0.05-2 \mathrm{~mm})$ content, $\mathrm{pH}_{\mathrm{H} 2 \mathrm{O}}, \mathrm{pH}_{\mathrm{KCl}}$, and specific density $\left(\rho_{\mathrm{s}}\right)$ (Kodešová et al., 2012).

\begin{tabular}{ccccccccc}
\hline Horizon & $\begin{array}{c}\text { Depth } \\
(\mathrm{cm})\end{array}$ & $\begin{array}{c}\mathrm{C}_{\mathrm{ox}} \\
(\%)\end{array}$ & $\begin{array}{c}\text { Clay } \\
(\%)\end{array}$ & $\begin{array}{c}\text { Silt } \\
(\%)\end{array}$ & $\begin{array}{c}\text { Sand } \\
(\%)\end{array}$ & $\begin{array}{c}\rho_{\mathrm{s}} \\
(\mathrm{g} \mathrm{cm})\end{array}$ & $\begin{array}{c}\mathrm{pH}_{\mathrm{H} 2 \mathrm{O}} \\
(-)\end{array}$ & $\begin{array}{c}\mathrm{pH}_{\mathrm{KCl}} \\
(-)\end{array}$ \\
\hline $\mathrm{Ap} 1$ & $0-25$ & 1.05 & 18.24 & 66.52 & 15.24 & 2.56 & 6.61 \\
$\mathrm{Ap} 2$ & $25-35$ & 0.66 & 21.49 & 59.61 & 18.9 & 2.61 & 6.21 \\
$\mathrm{Bt}_{1}$ & $35-75$ & 0.48 & 29.43 & 61.40 & 9.17 & 2.59 & 7.09 & 6.34 \\
$\mathrm{Bt}_{2}$ & $75-102$ & 0.28 & 23.03 & 63.53 & 13.44 & 2.60 & 7.11 & 6.56 \\
$\mathrm{Ck}$ & $102-103$ & 0.20 & 17.98 & 70.08 & 11.94 & 2.64 & 7.92 \\
\hline
\end{tabular}


(2010) documented (using DRIFT mapping) that coatings in this soil contain variable amounts of organic matter of different composition, which may influence the water infiltration rate. Fér and Kodešová (2012) showed that measured saturated hydraulic conductivities of aggregate coatings in the Bt2 horizon were one to two orders of magnitude lower than that of the soil aggregate interior. No statistically significant differences were found between saturated hydraulic conductivities obtained for coatings of various (clay-organic) compositions.

The Bt 2 Horizon was sampled as follows: Large intact soil blocks of approximate $30,000 \mathrm{~cm}^{3}$ were removed at depths of 75-102 cm from a soil pit using a spade, and were then wrapped in tinfoil. The blocks were transported within 1 day to the laboratory and stored in a refrigerator until analyzed. Individual aggregates were manually separated by carefully breaking the blocks according to the criteria that the samples should have at least two relatively plane intact sides with coated or uncoated surfaces (c.f., Leue et al., 2010, 2015). Some of the aggregates, and their selected side coatings, were cut by a scalpel to study the characteristics of the aggregate interior (i.e. not intact surfaces).

Three sets of samples were prepared. The first set, consisting of six air-dried aggregates, was used for the first measurements of water drop penetration time (WDPT) and contact angle (CA). Water droplets were applied at uncoated and coated regions of the surface of each aggregate. From these 6 aggregate samples, a total number of 23 individual measurements were obtained at intact clay-organic coatings (A), 31 individual measurements at intact coatings that mainly consisted of clay (B), 25 measurements at surfaces after removing the coatings using the scalpel (C), and 20 measurements at intact uncoated surfaces (D).

The second set of WDPT, CA, and DRIFT spectra measurements was carried out on the $2^{\text {nd }}$ set of 7 aggregates. In this case, initially air-dried aggregates were wetted using a sprayer and left for two weeks in plastic boxes in a refrigerator to achieve approximately the original soil-water contents. Using these wetted aggregates, WDPT and CA were measured at several different spots that represented intact coated and uncoated surfaces. From these 7 aggregate samples, a total of 22 individual measurements were carried out at intact clay-organic coatings $\left(E_{1}\right)$ and 7 at the uncoated surface $\left(F_{1}\right)$. Note that the uniformly dark colors of wet aggregate surfaces did not allow the visual separation between more clayey or organic coatings. The aggregates were then dried in a silica gel desiccator, and DRIFT spectra were measured at several spots of two or three sides of each aggregate (see below). Afterwards, WDPT and CA were measured on 23 spots with clay-organic coatings $\left(E_{2}\right)$ and on 25 spots where the aggregate surface was uncoated $\left(\mathrm{F}_{2}\right)$. Finally, aggregates were oven-dried and WDPT and CA measurements were repeated on 20 spots with clay-organic coatings $\left(\mathrm{E}_{3}\right)$ and another 20 spots that were uncoated $\left(\mathrm{F}_{3}\right)$.

The aggregate bulk density $\left(\rho_{d}\right)$ (Table 2 ) was measured using the $3^{\text {rd }}$ set of 8 aggregates (which were not used for the wettability testing) each in three repetitions using a GeoPyc 1360 (Micromeritics, Mönchengladbach). Values of $\rho_{d}$ and particle density, $\rho_{s}\left(2.59 \mathrm{~g} \mathrm{~cm}^{-3}\right)$, were used to calculate the volumetric soil water contents and the porosity of aggregates (Table 3).

The mineralogical composition of aggregate interiors and their coatings (i.e., clay-organic or clay) was characterized using X-ray diffraction. Sample material was obtained from coatings and aggregate interiors manually using a scalpel. For clay mineral identification, oriented aggregates of the $<2 \mu \mathrm{m}$ fraction were obtained by sedimentation. In the first step, samples were fully dispersed in water by means of ultrasound and repeated washing with deionized water. Next, the clay-size fraction (less than $2 \mu \mathrm{m}$ ) was separated by gravity sedimentation. The dispersed suspension of clay-size material was concentrated by ultracentrifugation, and then redispersed into a small volume of water. The suspension was then placed using an eye dropper on the zero diffraction silica plate, and the samples were dried at room temperature. The preparation of the oriented clay mineral aggregate is compatible with the procedure described in Moore and Reynolds (1997). X-ray powderdiffraction (XRD) analyses were carried out using a PANalytical X'Pert Pro diffractometer equipped with a diffracted-beam monochromator and $\mathrm{X}^{\prime}$ Celerator multichannel detector, using $\mathrm{Cu} \mathrm{Ka}$ radiation (40 keV, $30 \mathrm{~mA}$ ) (PANalytical B.V., Almelo, The Netherlands). Aggregates were scanned from $3^{\circ}$ to $70^{\circ}$ of the angle of diffraction $\left(2 \theta_{\mathrm{XRD}}\right)$, in steps of $0.02^{\circ}$, with a $200 \mathrm{~s}$ count time at each step. The diffraction data were analyzed using X'Pert HighScore Plus software, 1.0 version (PANalytical B.V., Almelo, The Netherlands).

\section{Water drop penetration time and contact angle measurement}

Droplet infiltration tests were performed at the intact aggregates according to Leue (2010) using a CA device coupled with a $1 \mathrm{~mL}$ syringe and a high-speed camera (OCA 20, DataPhysics, Filderstadt, Germany; Hamilton, Reno, Nevada). Penetration of the water drop of $6.3 \mu \mathrm{L}$ volume was recorded at a rate of 500 frames per second (i.e., $500 \mathrm{~Hz}$ ). All pictures were taken using the same light and camera conditions. Due to the

Table 2. Bulk densities $\left(\rho_{d}\right)$ of 8 aggregates from the Bt2 horizon: average values and standard deviations (SD) evaluated using GeoPyc 1360 .

\begin{tabular}{ccccccccccc}
\hline Aggregate & 1 & 2 & 3 & 4 & 5 & 6 & 7 & 8 & Average \\
\hline$\rho_{d}\left(\mathrm{~g} \mathrm{~cm}^{-3}\right)$ & 1.736 & 1.798 & 1.779 & 1.730 & 1.608 & 1.756 & 1.678 & 1.670 & 1.719 \\
$\mathrm{SD}\left(\mathrm{g} \mathrm{cm}^{-3}\right)$ & 0.0075 & 0.0006 & 0.0099 & 0.0036 & 0.0009 & 0.001 & 0.0035 & 0.006 & 0.004 \\
\hline
\end{tabular}

Table 3. Gravimetric soil water content $\left(w_{D}\right)$, volumetric soil-water content of the wet aggregates $\left(\theta_{W}\right)$ and for aggregates dried in desiccator $\left(\theta_{D}\right)$ for second set of aggregates. $\theta$ values were calculated assuming the average value of bulk density $\left(\rho_{d}=1.71 \mathrm{~g} \mathrm{~cm}^{-3}\right)$ and gravimetric soil water content $\left(w_{D}\right)$. Water saturation $(\mathrm{S})$ was calculated using the average porosity of $0.336 \mathrm{~cm}^{3} \mathrm{~cm}^{-3}$ and the values of $\theta_{W}$ for coated and uncoated aggregate samples that were wetted (E1, F1). Table shows average values and standard deviations (SD).

\begin{tabular}{cccccccccc}
\hline Aggregate & 1 & 2 & 3 & 4 & 5 & 6 & 7 & Average & SD \\
\hline$w_{D}\left(g^{-1}\right)$ & 0.23 & 0.17 & 0.23 & 0.20 & 0.17 & 0.18 & 0.17 & 0.19 & 0.028 \\
$\theta_{W}\left(\mathrm{~cm}^{3} \mathrm{~cm}^{-3}\right)$ & 0.39 & 0.30 & 0.41 & 0.34 & 0.29 & 0.31 & 0.28 & 0.33 & 0.051 \\
$\theta_{D}\left(\mathrm{~cm}^{3} \mathrm{~cm}^{-3}\right)$ & 0.03 & 0.03 & 0.03 & 0.05 & 0.03 & 0.02 & 0.03 & 0.03 & 0.009 \\
$\mathrm{~S}(-)$ & 0.98 & 0.88 & 0.98 & 0.97 & 0.86 & 0.91 & 0.84 & 0.92 & 0.060 \\
\hline
\end{tabular}


relatively rough surfaces of the aggregates the standard illumination method by a backlighting device could not be used. Thus, two high-power halogen bulbs of 50 watt each (Osram, Germany) were installed to illuminate the measurement areas of the water drop infiltration in-line with the direction of view of the camera. Video sequences were processed using the software SCA20 (DataPhysics) to obtain the WDPT (i.e. time difference between the first contact of the drop with the aggregate surface and the complete infiltration of the drop into the sample surface) and time series of CA values. Due to difficulties caused by relatively rough aggregate surfaces, only selected measurements from 2 spots on aggregate surface $\mathrm{A}, 2$ on $\mathrm{B}, 4$ on $\mathrm{C}, 3$ on $\mathrm{D}, 11$ on $\mathrm{E}_{1}, 6$ on $\mathrm{F}_{1}, 5$ on $\mathrm{E}_{2}$, and 5 on $\mathrm{F}_{2}$ were chosen from each group to evaluate time-related changes in CA. Assuming that the CA decreased exponentially with time (Leelamanie and Karube, 2009), experimental data were first fitted using the exponential equation:

$$
C A=C A_{0} e^{-k t}
$$

where $t$ represents time, $C A_{0}$ is the initial contact angle defined for the moment when the entire droplet is in first contact with the sample surface, and $k$ is the fitting parameter expressing the rate of the CA decrease. Since the decrease in CA with time was not successfully described by the exponential equation, the experimental data were also fitted by the power function:

$$
C A=a t^{-b}
$$

where $a$ and $b$ are the fitting parameters. The value of $a$ represents the CA at $t=1 \mathrm{~ms}$. The value of parameter $a$ strongly depends on the $b$ parameter expressing the curvature of the power function, which can be interpreted as the rate of the CA decrease. Since this power function approaches infinity for $t=$ 0 , likely higher $a$ values will be obtained for higher $b$ values and vice versa.

\section{DRIFT spectroscopy}

DRIFT spectroscopy was carried out on selected circular spots of about $1.5 \mathrm{~mm}^{2}$ in size at the aggregate surfaces as described previously (e.g., Ellerbrock et al., 2009; Leue et al., 2010). Briefly, the DRIFT spectra were recorded by 16 coadded scans between wave numbers (WN) 4000 and $400 \mathrm{~cm}^{-1}$ at a resolution of $4 \mathrm{~cm}^{-1}$ using a gold target as the background (99\% Infragold(C), Labsphere, North Sutton, NH, USA). The reflectance spectra were converted to Kubelka-Munk (KM) units (Kubelka, 1948) using WIN-IR Pro 3.4 (Digilab, Holliston, MA, USA). The spectra were smoothed with the boxcar moving average algorithm, applying a factor of 25 , and the baseline was corrected using one point at WN $4000 \mathrm{~cm}^{-1}$ and a second point in the range from WN 1200 to $1000 \mathrm{~cm}^{-1}$. The signal intensities of alkyl C-H groups (which act hydrophobic) (WN 2948 and $2920 \mathrm{~cm}^{-1}$ and WN 2864 and $2849 \mathrm{~cm}^{-1}$ ) were measured as the height from a local baseline. The signal intensities of carboxylic $\mathrm{C}=\mathrm{O}$ groups (which act hydrophilic) were measured in the regions between WN 1740 and $1698 \mathrm{~cm}^{-1}$ and between WN 1640 and $1600 \mathrm{~cm}^{-1}$. The potential wettability index (PWI) (Leue et al., 2013) of the SOM was calculated as the ratio between the summed signal intensities of the $\mathrm{C}-\mathrm{H}$ groups and the summed intensities of the $\mathrm{C}=\mathrm{O}$ groups (Ellerbrock et al., 2005).

\section{Statistical analysis}

Basic statistical analyzes were performed using Statgraphics Centurion XVII (STATGRAPHICS Centurion, 2014). Comparisons of PWI or WDPT for different surfaces of aggregates (A, $\mathrm{B}, \mathrm{C}$ and D types) were evaluated using ANOVA. Differences between results of WDPT measured at different types of aggregate surfaces $(\mathrm{E}$ and $\mathrm{F})$ in wet and dry conditions were evaluated using Student's t-test. Regression analysis was used to relate WDPT values to the parameters $a$ and $b$ (Equation (2)) measured on the first set of air-dried $(n=11)$ and on the second set of wet $(n=17)$ or dessicator-dried $(n=10)$ aggregates. Finally, regression analysis was used to relate PWI to the corresponding (i.e., measured at the same spot) WDPT values (10 spots on aggregate surface $\mathrm{E}_{1}, 8$ on $\mathrm{F}_{1}, 13$ on $\mathrm{E}_{2}$, and 20 on $\mathrm{F}_{2}$ ), and $a$ or $b$ parameters $\left(5\right.$ spots on aggregate surface $\mathrm{E}_{1}, 5$ on $\mathrm{F}_{1}, 6$ on $\mathrm{E}_{2}$, and 8 on $\mathrm{F}_{2}$ ).

\section{RESULTS AND DISCUSSION \\ Characteristics of clay in aggregate interiors and coatings}

Figure 1 shows the peak intensities at the characteristic positions of X-ray diffraction reflections $2 \theta_{\text {XRD }}\left({ }^{\circ}\right)$, which were measured on samples obtained from coatings and interiors of aggregates. Mineralogical compositions of the clay-organic and mostly clay aggregate coatings (i.e., samples A, and B in Figure 1) were almost the same. In both cases, the main clay minerals, evaluated according to Moore and Reynolds (1977), were vermiculite and illite, whereas minor clay minerals were kaolinite and illite-smectite. The aggregate interior and thus the surface of uncoated samples $(\mathrm{C}+\mathrm{D}$ in Figure 1) contained almost no illite, considerably lower contents of kaolinite and vermiculite in comparison to those in coatings, and a dominant content of illite-smectite, which is indicated by the very high peak value $(24313 \mathrm{cts})$ at an angle of 4.8 of $2 \theta_{\text {XRD }}$ (Figure 1).

Previous studies dealing with the impact of various clay minerals added to water repellent soils showed that kaolinite clay minerals usually reduced soil water repellency (Lichner et al., 2006; McKissock et al., 2000), while smectite clays also reduced soil repellency but to a lesser extent (McKissock et al., 2002). Illite is reported to increase the water repellency (Lichner et al., 2006). Thus, different clay mineralogy of the studied aggregate interiors and their coatings could also have an impact on different aggregate surface wettability, i.e. illite in aggregate coatings decreased the wettability of aggregate surfaces in comparison to that of the aggregate interior. However, the small number of measurements did not allow for quantification of the influence of the clay minerals in the studied soil in a more detailed way.

\section{Potential wettability of SOM at aggregate surfaces assessed by DRIFT spectroscopy}

Between 10 and 20 measurements of the DRIFT spectra were taken at each selected side of every aggregate (i.e. particular aggregate surface) of the second set. The summed signal intensities of $\mathrm{C}-\mathrm{H}$ and $\mathrm{C}=\mathrm{O}$ groups are shown in Table 4. The calculated PWI values (Figure 2) were lower for uncoated intact aggregate surfaces as compared to the coated ones, which agree with the results of Leue et al. (2013). Differences between clay-organic coated $\mathrm{E}(\mathrm{A})$ and uncoated $\mathrm{F}$, as well as between clayey coated $\mathrm{E}(\mathrm{B})$ and uncoated $\mathrm{F}$ surfaces were statistically significant at the $99 \%$ confidence level. The PWI values evaluated for $\mathrm{E}(\mathrm{A})$ surfaces were higher as compared to 


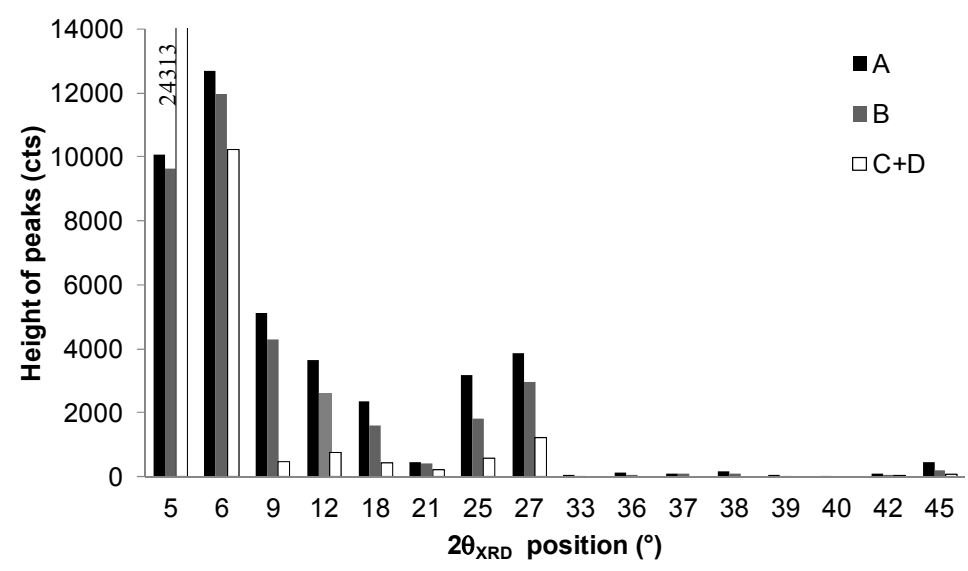

Fig. 1. Peak heights at different $2 \theta_{\text {XRD }}$ positions $\left({ }^{\circ}\right)$, derived from X-ray diffraction curves measured on samples prepared from coatings and interiors of aggregates: A clay-organic coatings, B - mostly clay coatings, C+D - aggregate interiors (i.e. measurement describes clay minerals of surfaces with organo-mineral coatings removed by a scalpel, and intact uncoated surfaces).

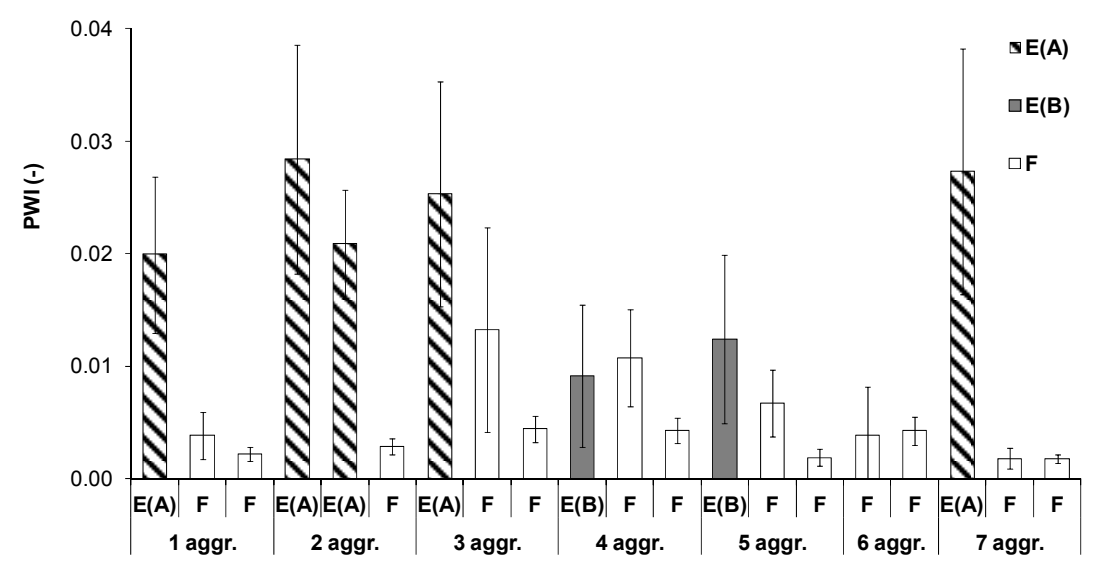

Fig. 2. Soil wettability expressed as PWI (-) measured on the second set of aggregates surfaces: E(A) - spots with clay-organic coatings, E(B) - spots with mostly clay coatings, and F - spots originally uncoated. Error bars indicate standard deviation.

Table 4. Number of analyzed DRIFT spectra, average values and standard deviations of summed signal intensities of $\mathrm{C}-\mathrm{H}$ and $\mathrm{C}=\mathrm{O}$ groups obtained from different surfaces of each aggregate: $\mathrm{E}(\mathrm{A})$ - spots with clay-organic coatings, $\mathrm{E}(\mathrm{B})$ - spots with mostly clay coatings, and $\mathrm{F}$ - spots originally uncoated.

\begin{tabular}{|c|c|c|c|c|c|c|}
\hline \multirow[t]{2}{*}{ Aggregate } & \multirow[t]{2}{*}{ Surface } & \multirow[t]{2}{*}{$\begin{array}{l}\text { No. of } \\
\text { replicates }\end{array}$} & \multicolumn{2}{|c|}{$\begin{array}{l}\text { C-H groups } \\
\text { (KM units) }\end{array}$} & \multicolumn{2}{|c|}{$\begin{array}{c}\mathrm{C}=\mathrm{O} \text { groups } \\
\text { (KM units) }\end{array}$} \\
\hline & & & $\begin{array}{c}\text { Average } \\
\text { value }\end{array}$ & $\begin{array}{l}\text { Standard } \\
\text { deviation }\end{array}$ & $\begin{array}{c}\text { Average } \\
\text { value }\end{array}$ & $\begin{array}{l}\text { Standard } \\
\text { deviation }\end{array}$ \\
\hline \multirow{3}{*}{1} & E(A) & 20 & 0.916 & 0.367 & 45.494 & 3.175 \\
\hline & $\mathrm{F}$ & 10 & 0.151 & 0.094 & 38.910 & 2.678 \\
\hline & $\mathrm{F}$ & 10 & 0.084 & 0.024 & 38.012 & 0.870 \\
\hline \multirow{3}{*}{2} & E(A) & 10 & 1.327 & 0.292 & 48.963 & 7.484 \\
\hline & $\mathrm{E}(\mathrm{A})$ & 10 & 0.104 & 0.023 & 36.489 & 1.821 \\
\hline & $\mathrm{F}$ & 10 & 0.951 & 0.203 & 45.863 & 2.433 \\
\hline \multirow{3}{*}{3} & $\mathrm{E}(\mathrm{A})$ & 20 & 0.997 & 0.350 & 40.415 & 3.454 \\
\hline & $\mathrm{F}$ & 12 & 0.539 & 0.432 & 38.202 & 4.173 \\
\hline & $\mathrm{F}$ & 10 & 0.190 & 0.053 & 42.725 & 0.956 \\
\hline \multirow{3}{*}{4} & $\mathrm{E}(\mathrm{B})$ & 10 & 0.398 & 0.254 & 44.893 & 2.758 \\
\hline & $\mathrm{F}$ & 12 & 0.674 & 0.289 & 61.993 & 3.117 \\
\hline & $\mathrm{F}$ & 10 & 0.179 & 0.044 & 42.446 & 1.879 \\
\hline \multirow{3}{*}{5} & $\mathrm{E}(\mathrm{B})$ & 20 & 0.789 & 0.453 & 64.717 & 5.649 \\
\hline & $\mathrm{F}$ & 10 & 0.288 & 0.126 & 43.075 & 1.083 \\
\hline & $\mathrm{F}$ & 10 & 0.074 & 0.028 & 40.006 & 1.667 \\
\hline \multirow[t]{2}{*}{6} & F & 10 & 0.151 & 0.169 & 39.960 & 1.542 \\
\hline & $\mathrm{F}$ & 10 & 0.180 & 0.052 & 42.658 & 1.957 \\
\hline \multirow{3}{*}{7} & E(A) & 20 & 1.166 & 0.380 & 43.435 & 3.665 \\
\hline & $\mathrm{F}$ & 12 & 0.068 & 0.034 & 37.724 & 2.237 \\
\hline & $\mathrm{F}$ & 12 & 0.068 & 0.015 & 37.707 & 1.169 \\
\hline
\end{tabular}


PWI values for $\mathrm{E}(\mathrm{B})$ surfaces. However, differences between $E(A)$ and $E(B)$ surfaces were not statistically significant at the $90 \%$ confidence level $(\mathrm{p}=0.103)$.

\section{Wettability of dry aggregates}

When studying droplet infiltration into the surfaces of the first set of air-dried soil aggregates, the highest WDPT values were measured for aggregates with the clay-organic coatings (the average value, $\mathrm{WDPT}_{\mathrm{A}}=4.07 \mathrm{~s}$, standard deviation, $\mathrm{SD}_{\mathrm{A}}=$ $2.275 \mathrm{~s}$ ). Surprisingly, almost identical WDPT results $\left(\mathrm{WDPT}_{\mathrm{B}}\right.$ $=2.42 \mathrm{~s}, \mathrm{SD}_{\mathrm{B}}=0.992 \mathrm{~s}$ and $\left.\mathrm{WDPT}_{\mathrm{C}}=2.45 \mathrm{~s}, \mathrm{SD}_{\mathrm{C}}=1.027 \mathrm{~s}\right)$ were obtained for aggregate surfaces with mostly clayey coatings and aggregates with coatings removed by a scalpel. The fastest penetration $\left(\mathrm{WDPT}_{\mathrm{D}}=0.73 \mathrm{~s}, \mathrm{SD}_{\mathrm{D}}=0.553 \mathrm{~s}\right)$ was measured for $\mathrm{D}$ (i.e., originally uncoated intact aggregate surfaces), probably because of the intact continuity of pores from the matrix up to the surface. The WDPT values of A were statistically significant different from B, C, and D at $99.9 \%$ confidence level, while that of $\mathrm{D}$ was significantly different from $\mathrm{B}$ and $\mathrm{C}$ at $99 \%$ confidence level. However, the WDPT was not significantly different between B and C (p-value $=0.889$ ). Modifications of intact surfaces of aggregates during sample preparation could explain why $\mathrm{WDPT}_{\mathrm{C}}$ was three times higher than $\mathrm{WDPT}_{\mathrm{D}}$. Despite the careful removal of coatings, some soil particles (including clay and organic matter) could have filled the aggregate interior pores, and the scraping could have smeared the cut surfaces. Filling and smearing might have decreased the pore sizes of the outermost aggregate surface leading to a reduced water infiltration.

For the classification of the persistence of water repellency, we used the range of the measured WDPT values (overall: 0.17 to $8.91 \mathrm{~s}$ ) and the classification of Dekker and Ritsema (1994). The aggregate surface types B (1.16-4.43 s), C (0.75-4.84 s) and D (0.17-2.1 s) could be defined as wettable (WDPT below 5 s). Only 7 spots (out of 23 spots) at aggregate surface type A $(0.87-8.91 \mathrm{~s})$ were defined as slightly water repellent. Our results of WDPT measurements are consistent with results obtained on aggregate surfaces from the Bt horizon of Haplic Luvisols by Leue et al. (2015), which were also described as wettable.

For all types of surfaces, the CA decreased with time (Figure $3)$. The non-linear decrease was initially $(<20 \mathrm{~ms})$ rapid and flattened out with time. However, fitting the exponential function (Eq. (1)) did not prove an exponential decrease of CA with time in contrast to previous studies (Chau et al., 2014; Leelamanie and Karube, 2009). Instead, the power function (Eq. (2)) could be better fitted to the data of all surface types (examples are shown in Figure 4). We found a statistically significant relationship $\left(R^{2}=0.84, \mathrm{p}<0.001\right)$ between the value of the $a$-parameter of the power function (indicating the CA at $t$ $=1 \mathrm{~ms}$ ) and the WDPT (Figure 5a). The relation between the value of the parameter $b$ (Eq. (2)) (i.e., the rate of the CA decrease $)$ and the WDPT $\left(R^{2}=0.61, \mathrm{p}<0.01\right)$ was also significant, but less pronounced (Figure $5 \mathrm{~b}$ ). Faster water droplet infiltration resulted in a higher $b$ value (i.e. rapid contact angle decrease) and higher $a$ value.

\section{Wettability of wet and dry aggregates}

The average WDPT values $\left(\mathrm{WDPT}_{\mathrm{E} 1}=18.1 \mathrm{~s}, \mathrm{SD}_{\mathrm{E} 1}=\right.$ $6.984 \mathrm{~s}$ and $\mathrm{WDPT}_{\mathrm{F} 1}=4.1 \mathrm{~s}, \mathrm{SD}_{\mathrm{F} 1}=2.214 \mathrm{~s}$ ) measured on wet soil samples of the second set of soil aggregates (soil water contents are shown in Table 3) were significantly higher than

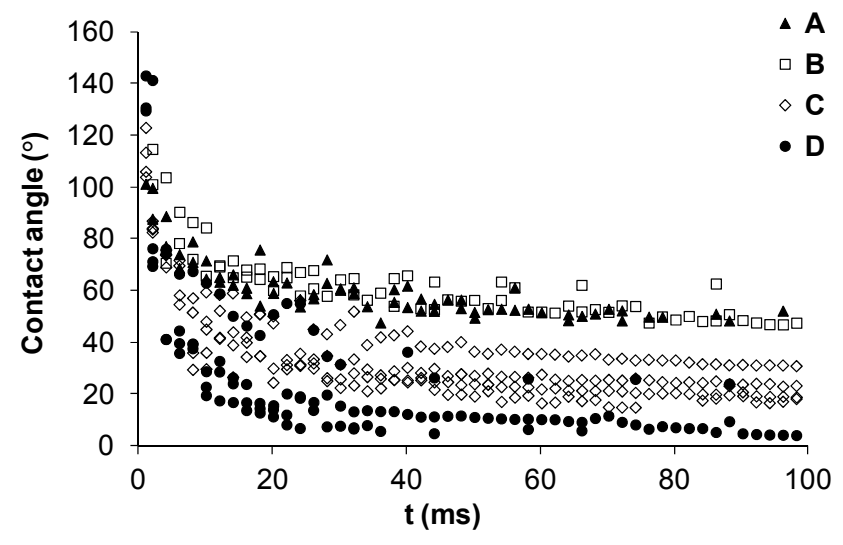

Fig. 3. Recorded contact angles during water drop penetrations for the first set of soil aggregates (air-dried), A - indicates surfaces with clay-organic coatings, B - surfaces with mostly clay coatings, C - surfaces with organo-mineral coatings removed by a scalpel, and D - intact uncoated surfaces.

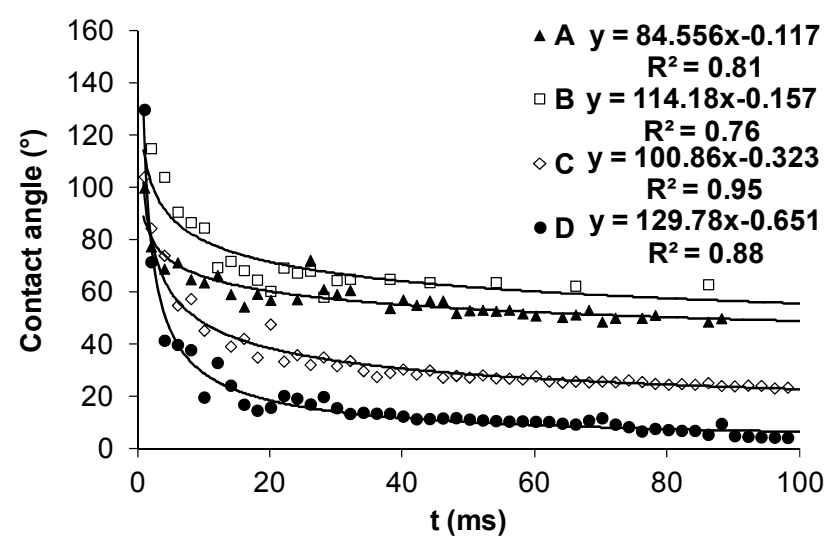

Fig. 4. Examples of recorded contact angles during water drop penetrations for the first set of soil aggregates (air-dried) and fitted power equation (Eq. (2)), A - indicates surfaces with clay-organic coatings, B - surfaces with mostly clay coatings, C - surfaces with organo-mineral coatings removed by a scalpel, and D - intact uncoated surfaces.

those measured on desiccator-dried and oven-dried soil samples $\left(\mathrm{WDPT}_{\mathrm{E} 2}=3.1 \mathrm{~s}, \mathrm{SD}_{\mathrm{E} 2}=1.401 \mathrm{~s}, \mathrm{WDPT}_{\mathrm{F} 2}=0.9 \mathrm{~s}, \mathrm{SD}_{\mathrm{F} 2}=0.459 \mathrm{~s}\right.$ and $\mathrm{WDPT}_{\mathrm{E} 3}=2.3 \mathrm{~s}, \mathrm{SD}_{\mathrm{E} 3}=1.225 \mathrm{~s}, \mathrm{WDPT}_{\mathrm{F} 3}=1.1 \mathrm{~s}, \mathrm{SD}_{\mathrm{F} 3}=$ $0.534 \mathrm{~s}$, for $\theta=0.01$ and $0.03 \mathrm{~cm}^{3} \mathrm{~cm}^{-3}$, respectively). This could be explained by a relatively high aggregate water contents, and consequently low hydraulic gradients, which resulted in larger infiltration times. There was no significant difference in WDPT of desiccator-dried and oven-dried samples. WDPT values measured at different surfaces $(\mathrm{E}$ and $\mathrm{F})$ showed significant $(\mathrm{p}<0.001)$ differences between the coated and uncoated soil surfaces for wet (i.e. E1 and F1), desiccator-dried (i.e. E2 and F2) or oven-dried (i.e. E3 and F3) aggregate surfaces.

For the wetted, and desiccator-dried, the temporal change in CA (Figure 6) could also be fitted by the power function (Eq. (2)). For the wetted samples, there were no significant relationships between neither parameter $a$ and WDPT $\left(R^{2}=0.21, \mathrm{p}=\right.$ $0.062)$ (Figure 7a) nor between $b$ and WDPT $\left(R^{2}=0.30 \mathrm{p}=\right.$ 0.023 ) (Figure $7 \mathrm{~b}$ ). The reason could be that the water drop penetration time in wet conditions was mainly affected by the pore size distribution and soil hydraulic properties, in contrast 


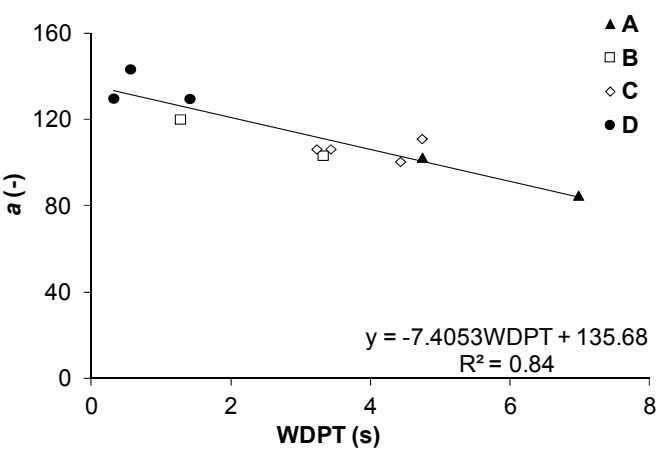

a)

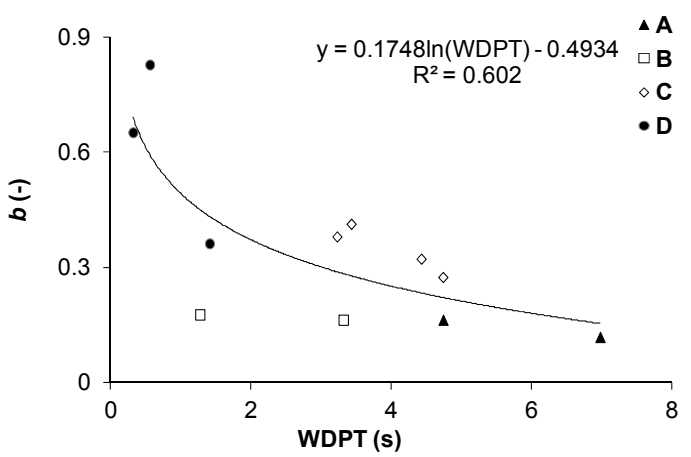

b)

Fig. 5. Relationships between $a$ (a) and $b$ (b) parameter of the power function (Eq. 2) and WDPT measured on the first set of soil aggregates (air-dried) where A - indicates surfaces with clayorganic coatings, B - surfaces with mainly clayey coatings, C surfaces with removed coatings, and D - intact uncoated surfaces.

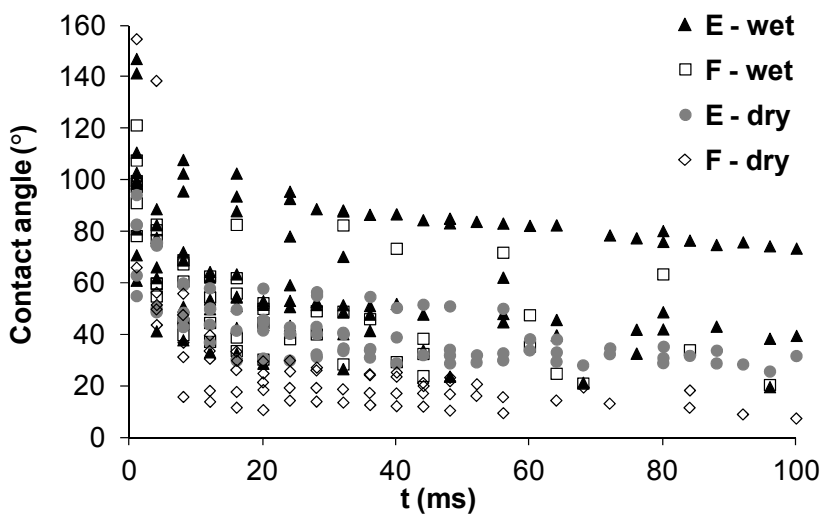

Fig. 6. Recorded contact angles during a water drop penetration for the second set of soil aggregates (desiccator-dried and wet), E indicates surfaces with clay-organic coatings and $\mathrm{F}$ - intact uncoated surfaces.

to the initially dominant influence of decreased wettability of aggregate surface under dry conditions. Another explanation was that despite all the efforts taken during the sample preparation, the soil water contents of individual aggregates when obtaining the WDPT measurements were not entirely identical (Table 3). Thus, WDPT was also controlled by hydraulic conditions that differed slightly between samples. For the desiccatordried surfaces, statistically significant relationships between $a$ and WDPT $\left(R^{2}=0.60 \mathrm{p}\right.$-value $\left.<0.01\right)$ (Figure 8a) as well as between $b$ and WDPT $\left(R^{2}=0.78 \mathrm{p}<0.001\right)$ were found (Figure $8 \mathrm{~b})$. However, when data obtained on both desiccator-dried (E2 and F2) and air-dried (A, B, C and D) aggregate surfaces were

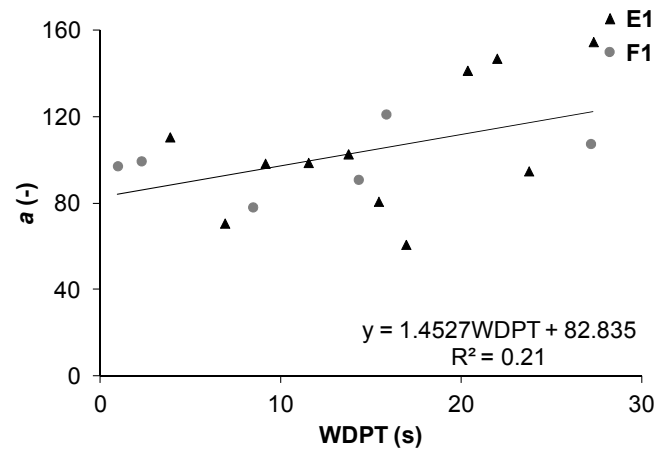

a)

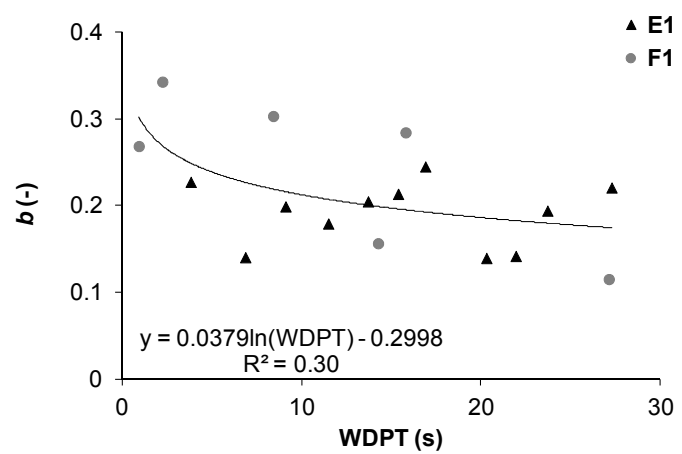

b)

Fig. 7. Relationships between $a$ (a) and $b$ (b) parameter of the power function (Eq. (2)) and WDPT measured on the second set of soil aggregates (wet), $\mathrm{E}_{1}$ - indicates surfaces with clay-organic coatings, $\mathrm{F}_{1}$ - intact uncoated surfaces.

used for analysis, considerably weaker correlations between $a$ and WDPT $\left(R^{2}=0.16 \mathrm{p}=0.07\right)$ and $b$ and WDPT $\left(R^{2}=0.34 \mathrm{p}\right.$ $=0.005$ ) (Figure not shown) were found. The reason might be that the treatment process of the second set of aggregates (i.e. wetting and drying, performing droplet infiltration tests under different moisture conditions, analyzing DRIFT spectra) caused surface mechanical disturbances, which resulted in different droplet behaviors in comparison to that on the surface of the first set of aggregates that were only air-dried.

\section{WDPT explained by PWI of SOM at aggregate surfaces}

A relatively close linear relationship (Figure 9) was found between PWI and WDPT values for desiccator-dried and wetted $\mathrm{E}$ and $\mathrm{F}$ type surfaces $\left(R^{2}=0.75, \mathrm{p}<0.001\right.$ and $R^{2}=0.64, \mathrm{p}$ $<0.05)$. These results indicated decreasing soil wettability with increasing SOM contents, as well as with increasing proportions of aliphatic groups of the SOM (Leue et al., 2015). However, larger WDPT values measured at surfaces with coatings than those at uncoated surface were also associated with generally lower hydraulic conductivity of coatings (consisted of fine grained material) in comparison to hydraulic conductivity of aggregate interiors. Considerable differences between the hydraulic conductivities of aggregate coating and interiors were observed for soil aggregates taken from the same soil horizon by Fér and Kodešová (2012) and Kodešová et al. (2012). Results of our measurements on dry soil samples showed a slightly different relationship between WDPT and PWI, than those results of Leue et al. (2015), who observed a non-linear relationship between PWI and WDPT $(R=0.5, \mathrm{p}<0.001)$ for different types of preferential flow path surfaces. One reason 


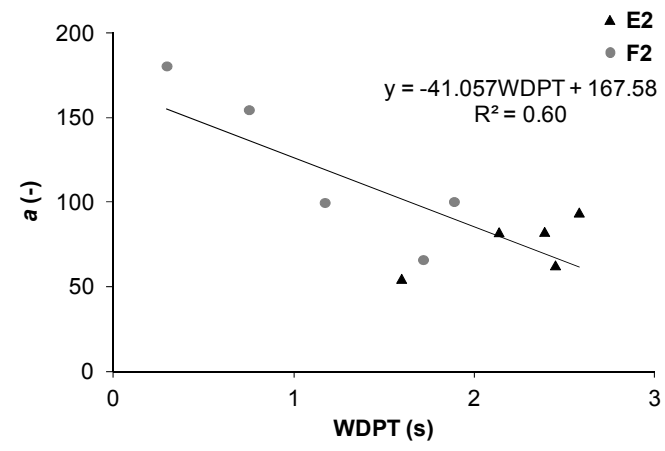

a)

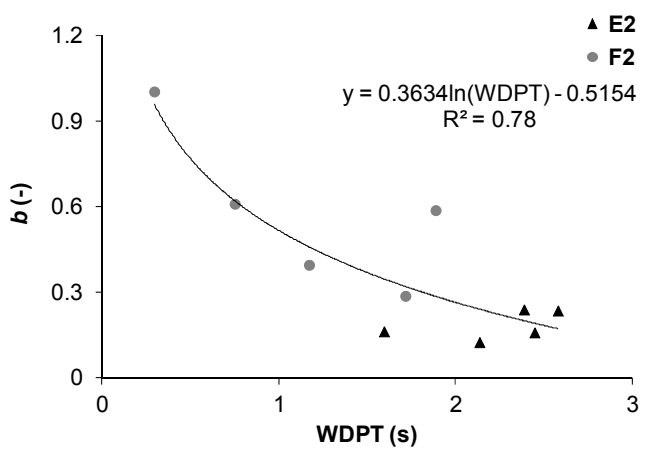

b)

Fig. 8. Relationships between $a$ (a) and $b$ (b) parameter of the power function (Eq. (2)) and WDPT measured on the second set of soil aggregates (desiccator-dried), $\mathrm{E}_{2}$ - indicates surfaces with clayorganic coatings, $F_{2}$ - intact uncoated surfaces.

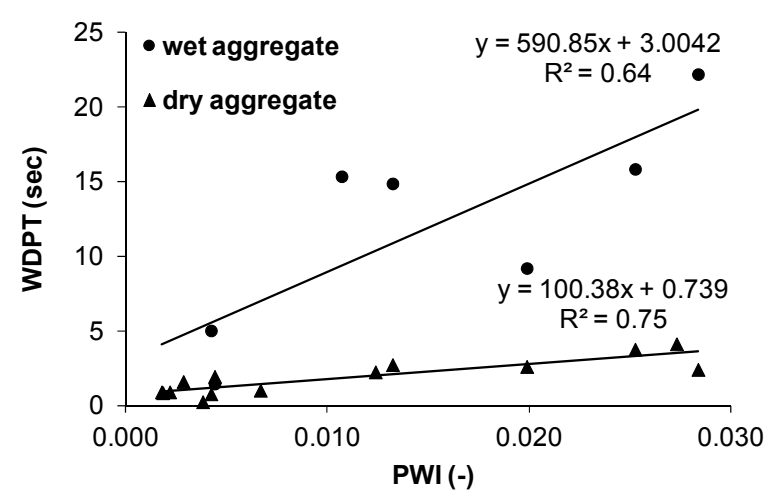

Fig. 9. Relationships between PWI and WDPT for wet and desiccator-dried soil samples (second set of aggregates).

for this difference might be that the PWI values obtained in this study for surfaces with organo-mineral coatings were 2- or 3times higher than those obtained by Leue et al. (2015) for surfaces with organo-mineral coating from the Bt layer of the same soil. However, for larger WDPTs (i.e., between 2.5 and $8 \mathrm{~s}$ ), Leue et al. (2015) found a linear relationship between WDPT and PWI in line with our results here.

Results of the regression analyses relating PWI and $a$ or PWI and $b$ corresponded to those for WDPT and $a$ or WDPT and $b$. No correlation (Figure 10a and 10b) was observed between PWI and $a$, or PWI and $b$ for wet $\left(\mathrm{E}_{1}\right.$ and $\left.\mathrm{F}_{1}\right)$ surfaces $\left(R^{2}=0.02, \mathrm{p}\right.$-value $=0.670$ and $R^{2}=0.18, \mathrm{p}$-value $\left.=0.130\right)$, although these relationships were statistically significant (Figure 11a and $11 \mathrm{~b}$ ) for desiccator-dry (i.e. $\mathrm{E}_{2}$ and $\mathrm{F}_{2}$ ) surfaces $\left(R^{2}=0.64, \mathrm{p}<0.05\right.$, and $R^{2}=0.53$, $\mathrm{p}$-value $\left.<0.05\right)$.

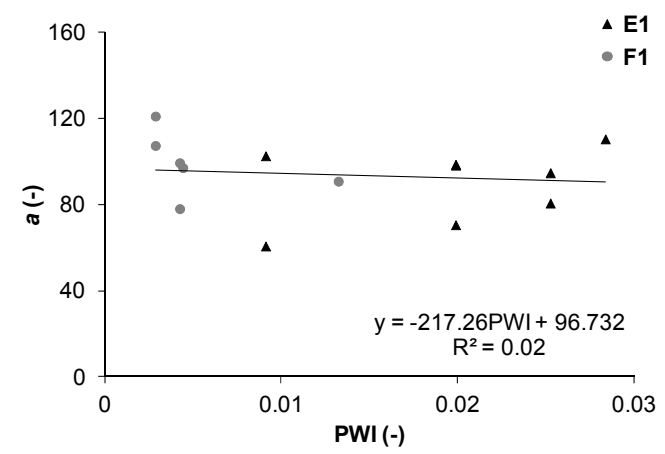

a)

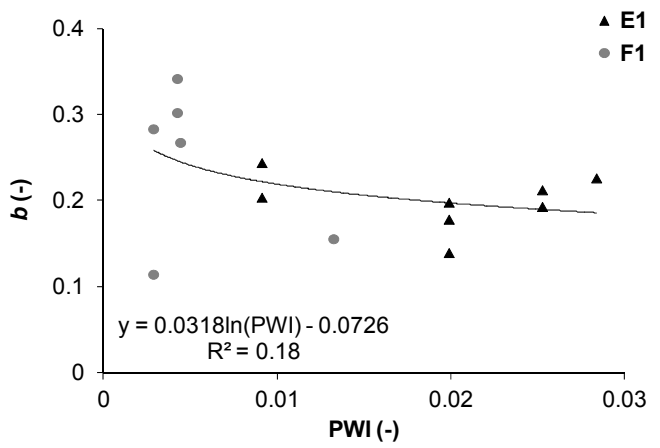

b)

Fig. 10. Relationships between $a$ (a) and $b$ (b) parameter of the power function (Eq. (2)) and PWI measured on the second set soil aggregates (wet), $E_{1}$ - indicates surfaces with clay-organic coatings, $F_{1}$ - intact uncoated surfaces.

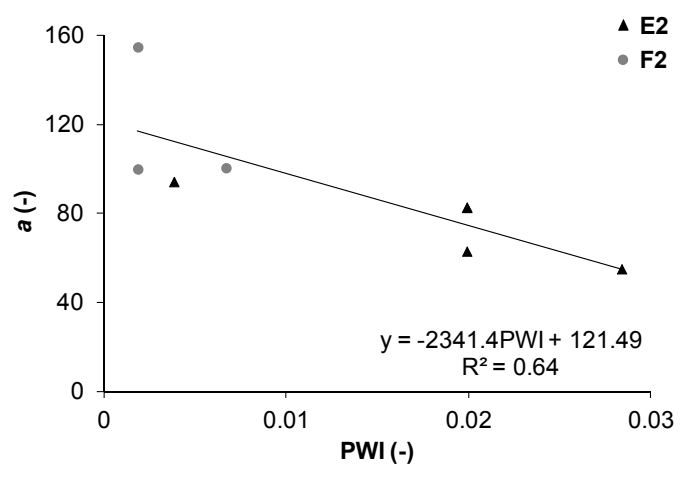

a)

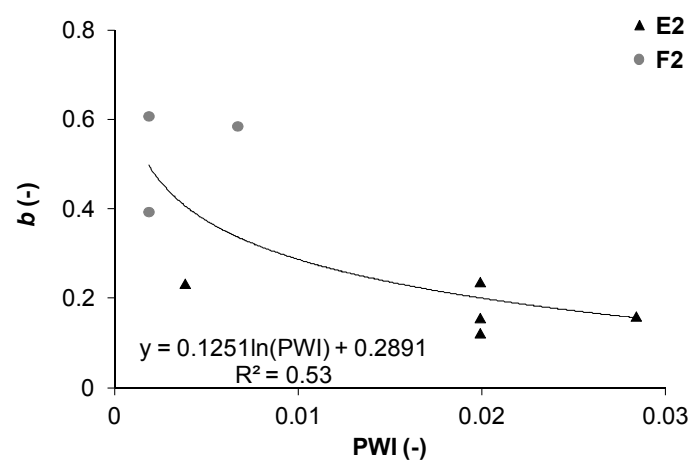

b)

Fig. 11. Relationships between (a) parameter $a$ and (b) parameter $b$ of the power function (Eq. (2)) and PWI measured on the second set of soil aggregates (desiccator-dried); $E_{2}$ - indicates surfaces with clay-organic coatings, $\mathrm{F}_{2}$ - intact uncoated surfaces. 
Droplet infiltration dynamics and soil wettability related to soil organic matter of soil aggregate coatings and interiors

\section{CONCLUSIONS}

Wettability of intact soil aggregate surfaces with and without coatings from a $\mathrm{Bt} 2$ horizon of a Haplic Luvisol was assessed using WDPT, temporal changes of the CA, the PWI obtained from DRIFT spectra, and the clay mineralogy as shown by Xray diffraction. WDPT and CA were measured on a set of 6 airdried aggregates (first set), and on 7 wetted, desiccator-dried and oven-dried aggregates (second set). PWI was determined for the desiccator-dried samples. Clay mineralogical composition was measured on samples prepared from aggregate clay coatings and interiors. A power function was used to describe the changes in CA with time. Results showed that coatings considerably decreased droplet infiltration, i.e. increased infiltration times. Actual (WDPT) and potential wettability (PWI) characteristics were positively related in both desiccator-dried and wet soil samples. Both characteristics (PWI and WDPT) determined for desiccator-dried samples and WDPT measured for air-dried samples were negatively related to the $a$ parameter (i.e. the initial CA value for $t=1 \mathrm{~ms}$ ) and the $b$ parameter (i.e. the curvature) of the power function. This indicates that the SOM composition (characterized as PWI) influences CA dynamics. The power function parameters $a$ and $b$ increased (i.e. rate of CA decrease increased) with PWI of SOM. The clay mineral composition inside aggregates was different from that of their coatings, which could have affected the wettability of aggregate coatings. However, further analysis is needed to reveal the influence of organic and mineral components on wettability of intact aggregate surfaces. The results suggest that the effect of the SOM composition of coatings on surface wettability decreases with increasing soil moisture. For wet aggregates (possibly more representative of real conditions in the subsoil than dried aggregates), the effect of soil hydraulic properties controls the infiltration rather than the SOM composition. However, the relations between actual and potential wettability of the organic matter of aggregate coatings may also improve understanding of mass exchange processes during preferential flow processes in structured soils.

Acknowledgements. Authors acknowledge the financial support of the Czech Science Foundation No. 13-12477S and of the 'Deutsche Forschungsgemeinschaft, Bonn' (DFG) under grants EL191/7-2 ('In situ characterization of soil organic substances at surfaces of preferential flow, soil aggregates and biopores') and LE3177/1-1 ('Quantification of small-scale physicochemical properties of intact macropore surfaces in structured soils'). Authors thank Petr Drahota for measuring X-ray diffraction of soil aggregates. Authors also acknowledge Renata Hypscher from the Institute of Soil Landscape Research, Leibniz-Centre for Agricultural Landscape Research (ZALF) for their help in the field and laboratory. Authors also thank Christopher Ash for English language correction.

\section{REFERENCES}

Bachmann, J., Goebel, Marc-O., Woche, S.K., 2013. Smallscale contact angle mapping on undisturbed soil surfaces. Journal of Hydrology and Hydromechanics, 611, 3-8.

Blanco-Canqui, H., Lal, R., 2009. Extent of soil water repellency under long-term no-till soils. Geoderma, 149, 171-180.

Capriel, P., Beck, T., Borchert, H., Gronholz, J., Zachmann, G., 1995. Hydrophobicity of the organic matter in arable soils. Soil Biology and Biochemistry, 27, 1453-1458.

Celi, L., Schnitzer, M., Nègre, M. 1997. Analysis of carboxyl groups in soil humic acids by a wet chemical method, Fourier- transform infrared spectroscopy and solution-state Carbon13 nuclear magnetic resonance. A comparative study. Soil Science, 162, 189-197.

Chau, H.W., Biswas, A., Vujanovic, V., Si, B.S., 2014. Relationship between the severity, persistence of soil water repellency and the critical soil water content in water repelent soils. Geoderma, 221-222, 113-220.

Czachor, H., Hallett, P.D., Lichner, L., Jozefaciuk, G., 2013. Pore shape and organic compounds drive major changes in the hydrological characteristics of agricultural soil. European Journal of Soil Science, 64, 334-344.

Dekker, L.W., Ritsema, C.J., 1994. How water moves in a water repellent sandy soil. 1. Potential and actual water repellency. Water Resources Research, 30, 2507-2517.

Demyan, M.S., Rasche, F., Schulz, E., Breulmann, M., Muller, T., Cadish, G., 2012. Use of specific peaks obtained by diffuse reflectance Fourier transformation mid-infrared spectroscopy to study the composition of organic matter in Haplic Chernozem. European Journal of Soil Science, 63, 189199.

Ellerbrock, E.H., Gerke, H.H., Bachman, J., Goebel, M.O., 2005. Composition of organic matter fractions for explaining wettability of three forest soils. Soil Science Society of America Journal, 69, 57-66.

Ellerbrock, E.H., Gerke, H.H., Böhm, Ch., 2009. In situ DRIFT characterization of organic matter composition on soil structural surfaces. Soil Science Society of America Journal, 73, 531-540.

Fér, M., Kodešová, R., 2012. Estimating hydraulic conductivities of the soil aggregates and their clay-organic coatings using numerical inversion of capillary rise data. Journal of Hydrology, 468-469, 229-240.

Gerke, H.H., 2012. Macroscopic representation of the interface between flow domains in structured soil. Vadose Zone Journal, 113, 2012.

Gerke, H.H., Köhne, J.M., 2002. Estimating hydraulic properties of soil skins from sorptivity and water retention. Soil Science Society of America Journal, 66, 26-36.

Goebel, M.-O., Bachmann, J., Woche, S.K., Fischer, W.R., 2005. Soil wettability, aggregate stability, and the decomposition of soil organic matter. Geoderma, 128, 80-93.

Goebel, M.-O., Bachmann, J., Woche, S.K., 2008. Modified technique to assess the wettability of soil aggregates: Comparison with contact angles measured on crushed aggregates and bulk soil. European Journal of Soil Science, 59, 12411252.

IUSS Working Group WRB, 2014. World Reference Base for Soil Resources 2014. International soil classification system for naming soils and creating legends for soil maps. World Soil Resources Reports No., 106, FAO, Rome.

Jirků, V., Kodešová, R., Nikodem, A., Mühlhanselová, M., Žigová, A., 2013. Temporal variability of structure and hydraulic properties of topsoil of three soil types. Geoderma, 204-205, 43-58.

Jouquet, P., Bottinelli, N., Podwojewski, P., Hallaire, V., Tran Duc, T., 2008. Chemical and physical properties of earthworm casts as compared to bulk soil under a range of different land-use system in Vietnam. Geoderma, 146, 231-238.

Kočárek, M., Kodešová, R., Kozák, J., Drábek, O., 2010. Field study of chlorotoluron transport and its prediction by the BPS mathematical model. Soil and Water Research, 4, 153160.

Kodešová, R., 2009. Soil micromorphology use for modeling of a non-equilibrium water and solute movement. Plant, Soil and Environment, 55, 424-428. 
Kodešová, R., Kočárek, M., Kodeš, V., Šimůnek, J., Kozák, J., 2008. Impact of soil micromorphology features on water flow and herbicide transport in soils. Vadose Zone Journal, 7, 798-809.

Kodešová, R., Vignozzi, N., Rohošková, M., Hájková, T., Kočárek, M., Pagliai, M., Kozák, J., Šimůnek, J., 2009. Impact of varying soil structure on transport processes in different diagnostic horizons of three soil types. Journal of Contaminant Hydrology, 104, 107-125.

Kodešová, R., Šimůnek, J., Nikodem, A., Jirků V., 2010. Estimation of the dual-permeabillity model parameters using tension disk infiltrometer and Guelph permeameter. Vadose Zone Journal, 9, 213-225.

Kodešová, R., Jirků, V., Kodeš, V., Mühlhanselová, M., Nikodem, A., Žigová, A., 2011. Soil structure and soil hydraulic properties of Haplic Luvisol used as arable land and grassland. Soil and Tillage Research, 1112, 154-161.

Kodešová, R., Němeček, K., Kodeš, V., Žigová, A., 2012. Using dye tracer for visulization of preferential flow at macro- and microscales. Vadose Zone Journal, 11, 1-10.

Kodešová, R., Němeček, K., Žigová, A., Nikodem, A., Fér, M., 2015. Using dye tracer for visualizing roots impact on soil structure and soil porous system. Biologia, 70, 11, 14391443.

Kořenková, L., Šimkovič, I., Dlapa, P., Juráni, B., Matúš, P., 2015. Identifying the origin of soil water repellency at regional level using multiple soil characteristics: The White Carpathians and Myjavska Pahorkatina Upland case study. Soil and Water Research, 10, 78-89.

Köhne, J.M., Gerke, H.H., Köhne, S., 2002. Effective diffusion coefficients of soil aggregates with surface skins. Soil Science Society of America Journal, 66, 1430-1438.

Kubelka, P., 1948. New contributions to the optics of intensely light-scatering materials. Part I. J. Opt. Soc. Am., 38, 448457.

Lachacz, A., Nitkiewicz, M., Kalisz, B., 2009. Water repellency of post-boggy soils with a various content of organic matter. Biologia, 643, 634-638.

Leelamanie, D.A.L., Karube, J., 2007. Effects of organic compounds, water content and clay on the water repellency of a model sandy soil. Soil Science and Plant Nutrition, 536, 711-719.

Leelamanie, D.A.L., Karube, J., 2009. Time dependence of contact angle and its relation to repellency persistence in hydrophobized sand. Soil Science and Plant Nutrition, 554, 457-461.

Leelamanie, D.A.L., Karube, J., 2011. Water-dependent repellency of model soils as affected by clay. Soil Science and Plant Nutrition, 571, 7-10.

Leelamanie, D.A.L., Karube, J., Yoshida, A., 2010. Clay effects on the contact angle and water drop penetration time of modeled soils. Soil Science and Plant Nutrition, 563, 371375.

Leue, M., Ellerbrock, R.H., Gerke, H.H., 2010. DRIFT mapping of organic matter composition at intact soil aggregate surfaces. Vadose Zone Journal, 9, 317-324.

Leue, M., Gerke, H.H., Ellerbrock, R.H., 2013. Millimetrescale distribution of organic matter composition at intact biopore and crack surfaces. European Journal of Soil Science, 64, 757-769.
Leue, M., Gerke, H.H., Godow, S., 2015. Droplet infiltration and organic matter composition of intact crack and biopore surfaces from clay-illuvial horizons. Journal of Plant Nutrition and Soil Science, 178, 250-260.

Lichner, L., Dlapa, P., Doerr, S.H., Mataix-Solera, J., 2006. Evaluation of different clay minerals as aditives for soil water repellency allevation. Applied Clay Science, 31, 238248.

Lipiec, J., Turski, M., Hajnos, M., Świeboda, R., 2015. Pore structure, stability and repellency of earthworm casts and natural aggregates in loess soil. Geoderma, 243-244, 124129.

McKissock, I., Walker, E.L., Gilkes, R.J., Carter, D.J., 2000. The influence of clay type on reduction of water repellency by applied clays. a review of some West Australian work. Journal of Hydrology, 231-232, 323-332.

McKissock, I., Gilkes, R.J.,Walker, E.L., 2002. The reduction of water repellency by added clay is influenced by clay and soil properties. Applied Clay Science, 20, 225-241.

Moore, D., Reynolds, R.R., 1997. X-Ray Diffraction and the Identification and Analyzis of Clay Minerals, 2nd ed. Oxford, New York. Oxford University Press. ISBN 0195087135, $378 \mathrm{p}$.

Nobles, M.M., Wildings, L.P., McInnes, K.J., 2003. Soil structural interfaces in some Texas Vertisols and their impact on solute transport. Catena, 543, 477-493.

Nobles, M.M., Wildings, L.P., McInnes, K.J., 2004. Submicroscopic measurements of tracer distribution related to surface features of soil aggregates. Geoderma, 123, 83-97.

Rogasik, H., Schrader, S., Onasch, I., Kiesel, J., Gerke, H.H., 2014. Micro-scale dry bulk density variation around earthworm Lumbricus terrestris L. burrows based on X-ray computed tomography. Geoderma, 213, 471-477.

Schaumann, G.E., Diehl, D., Bertmer, M., Jeger, A., Conte, P., Alonzo, G., Bachmann, J., 2013. Combined proton NMR wideline and NMR relaxometry to study SOM-water interaction of creation-treated soils. Journal of Hydrology and Hydromechanics, 61, 1, 50-63.

Schrader, S., Rogasik, H., Onasch, I., Jégou, D., 2007. Assessment of soil structural differentiation around earthworm burrows by means of X-ray computed tomography and scanning electron microscopy. Geoderma, 137, 378-387.

STATGRAPHICS Centurion, 2014. STATGRAPHICS Centurion XVII. User Manual. Version 17.1.8.0

Vogelmann, E.S., Reichert, J.M., Prevedello, J., Consensa, C.O.B., Oliveira, A.É., 2013. Threshold water content beyond which hydrophobic soil become hydrophilic. The role of soil texture and organic matter content. Geoderma, 209210, 177-187.

Woche, S.K., Goebel, M.-O., Kirkham, M.B., Horton, R., Van der Ploeg, R.R., Bachmann, J., 2005. Contact angle of soils as Affected by depth, texture and land management. European Journal of Soil Science, 56, 239-251.

Zavala, L.M., García-Morena, J., Gordillo-Rivero, Á.J., Jordán, A., Mataix-Solera, J., 2014. Natural soil water repellency in different types of Mediterranean woodlands. Geoderma, 226-227, 170-178.

Received 11 December 2015 Accepted 11 March 2016 